\title{
Yield, Growth, and Mineral Nutrition of Young 'Ray Ruby' Grapefruit Trees under Trickle or Flood Irrigation and Various Nitrogen Rates
}

\author{
Dariusz Swietlik ${ }^{1}$ \\ Texas A\&I University Citrus Center, P.O. Box 1150, Weslaco, TX 78596 \\ Additional index words. Citrus paradisi, irrigation scheduling, root distribution, water stress, water use
}

\begin{abstract}
Growth, fruiting, and mineral nutrition of trickle- or flood-irrigated young 'Ray Ruby' grapefruit (Citrus paradisi Macf.) trees on sour orange $(C$. aurantium L.) rootstock were compared in a 4-year field study. Trickle irrigations (two emitters per tree) were scheduled based on: 1) 0.7 (first 3 years) or 0.5 (4th year) of Class A pan evaporation (TPAN) adjusted to the ground area covered by tree canopies, or 2) tensiometer readings (TTEN) of - 0.02 MPa at 30-cm soil depth. The flood irrigations (FLOOD) were scheduled at $50 \%$ available soil water depletion at $30 \mathrm{~cm}$ (first 3 years) or 30 - and 60-cm soil depth (the 4th year). Nitrogen at $\mathrm{NO}$ (none), $\mathrm{N}_{1}(20,40,80,160 \mathrm{~g} \mathrm{~N} /$ tree per year in the four consecutive years), or $\mathrm{N}_{2}$ (twice the amount of $\mathrm{NJ}$ was injected into the trickle lines from January to August or, under FLOOD, split into January and May soil applications. TPAN and TTEN trees were irrigated with $<10 \%$ of the water amount applied to FLOOD trees without negatively affecting tree growth, yield, or fruit size. Growth of the trees was not affected by $\mathbf{N}$ fertilization, but fruit count and yield and leaf $\mathbf{N}$ concentration were increased by the $\mathrm{N}_{1}$ and $\mathrm{N}_{2}$ treatments in the fourth growing season. Frequent $\mathrm{N}$ fertigations under the trickle system provided no benefits over two split-soil broadcast applications under the flood system. Fruit size was reduced by the $\mathrm{N}_{2}$ treatment. Based on the water amounts applied to TTEN trees, irrigation needs under the trickle system were estimated to be $0.75,0.57,0.30$, and 0.20 of Class $\mathrm{A}$ pan evaporation adjusted to the ground area covered by the plant canopies, in the first, 2nd, 3rd, and 4th year of orchard life. The decreasing pan coefficient indicated increasing extraction of water from outside the irrigated zones. Roots of TPAN and TTEN trees grew at least $210 \mathrm{~cm}$ past the wetted zones into the row middles. More than half of the roots in the TPAN and TTEN treatments were found at $60-$ to $230-\mathrm{cm}$ soil depth compared to only $17 \%$ in the FLOOD treatment.
\end{abstract}

Flood irrigation is the most common method of irrigating citrus orchards in the subtropical Rio Grande Valley of Texas. Increased competition between agricultural and nonagricultural water users has created a need for more efficient irrigation technologies such as low-volume irrigation. However, the potential benefits of this technology have not been fully investigated.

Research on low-volume irrigation of young citrus orchards has been limited in Texas and other citrus-growing areas. In Arizona, Roth et al. (1974) reported that trickle-irrigated young 'Valencia' orange [Citrus sinensis (L.) Osh.] trees grew more vigorously than those grown with flood or limited-coverage sprinkler irrigation. In Texas, young 'Star Ruby' grapefruit trees grew equally well under trickle and flood irrigation, but no detailed information was given on trickle irrigation scheduling (Leyden, 1975a). In Florida, Marler and Davies (1990) reported young 'Hamlin' orange trees grew best when microsprinkler irrigations were initiated at soil water depletions of $20 \%$ to $45 \%$. Smajstrla et al. (1985) demonstrated that young 'Valencia' orange trees grew best when irrigations were scheduled at -0.02 $\mathrm{MPa}$ soil matrix potential. Fruiting of young trees was not investigated in any of these studies.

Many reports have been published on scheduling low-volume irrigations in mature citrus orchards (Bielorai, 1982; Bielorai et al., 1985; Koo, 1985; Koo and Smajstrla, 1985; Smajstrla and Koo, 1984). In Texas, Leyden (1975b) estimated irrigation needs of grapefruit orchards at 0.7 pan evaporation adjusted to the area covered by the plant canopy. Research on peaches [Prunus persica (L.) Batsch] in Australia, however, showed that em-

Received for publication on 22 May 1991. Accepted for publication 28 Aug. 1991, The technical assistance of J.V. LaDuke is gratefully acknowledged. The cost of publishing this paper was defrayed in part by the payment of page charges. Under postal regulations, this paper therefore must be hereby marked advertisement solely to indicate this fact.

'Associate Professor. ploying universal irrigation formulas for all tree ages may result in marked underwatering of young trees (Black et al., 1977).

Assuming that frequent $\mathrm{N}$ fertigations over most of the growing season stimulate vegetative growth due to the constant availability of $\mathrm{N}$ in the root environment, a parallel may be drawn to the steady supply of $\mathrm{N}$ from slow-release fertilizers. These materials were shown to increase the growth of young orange trees compared to standard fertilizers (Koo, 1989). Our knowledge on the benefits of frequent $\mathrm{N}$ fertigations in young orchards is still limited, but the most recent report by Willis et al. (1991) indicates no growth improvements in the first year after planting. However, longer term data are needed.

The objectives of this study were to: 1) compare the effects of trickle vs. flood irrigation on young citrus tree growth, yield, nutritional status, root distribution, and water use; 2) determine tree responses to various $\mathrm{N}$ application rates and frequencies under trickle and flood irrigation; 3) estimate irrigation requirements of trickle-irrigated trees.

\section{Materials and Methods}

Plant material, site, and treatments. Balled-and-burlaped trees of 'Ray Ruby' grapefruit on sour orange rootstock were planted at 8.5 x $4.6 \mathrm{~m}$ spacing in May 1986 and immediately floodirrigated. The soil was of the Raymondville series (fine, mixed, hyperthermic Vertic Calciustolls), with the surface 90 to 130 $\mathrm{cm}$ of clay or sandy clay underlain by sandy clay loam. The soil is calcareous within the whole profile, with a $\mathrm{pH}$ of 7.5 to 8.0 in the top $60 \mathrm{~cm}, 1 \%$ organic matter in the top $30 \mathrm{~cm}$, and a typical available, volumetric soil water content of $14.9 \%$, $11.8 \%$, and $12.6 \%$ at $\mathrm{O}$ to 30,30 to 60 , and 60 to $90 \mathrm{~cm}$ depths,

Abbreviations: FLOOD. flood irrigations; RLD, root length density; TPAN, trickle irrigations scheduled based on Class A pan evaporation; TTEN, trickle irrigations scheduled based on tensiometer readings. 
respectively. The water table was at a depth of $260 \mathrm{~cm}$. During the study, the entire orchard floor was under chemical weed control and standard disease and insect control practices were followed.

One flood and two trickle irrigation treatments were initiated in Aug. 1986. Trickle irrigation was scheduled based on: 1) 0.7 (first 3 years) or 0.5 (4th season) of Class A pan evaporation adjusted to the mean ground area covered by tree canopies (TPAN), or 2) an average tensiometer reading of $-0.02 \mathrm{MPa}$ at 30 -cm soil depth (TTEN), which corresponded to $\approx 16 \%$ available soil water depletion: The pan coefficient of 0.7 was used previously by Leyden (1975b) to calculate trickle irrigation amounts for mature citrus trees in Texas. The TTEN treatment served to develop more precise guidelines for trickle irrigation amounts and relating these amounts to Class A pan evaporation, adjusted to the ground area covered by tree canopies. The assumption was made that water was not a limiting factor when irrigations were initiated at $-0.02 \mathrm{MPa}$ soil water potential. As growers typically do, $15 \mathrm{~cm}$ of water was applied with each FLOOD to plots confined within permanent soil borders. Irrigations were initiated whenever average neutron probe readings (one access tube per plot) indicated 50\% available soil water depletion at $30 \mathrm{~cm}$ (first 3 years) or at 30 - and $60-\mathrm{cm}$ depth (4th year). With this approach, the number of flood irrigations applied was similar to that used by area growers. A nonirrigated treatment was not included because newly planted trees were not likely to survive without supplemental irrigation.

Three levels of $\mathrm{N}\left(\mathrm{N}_{0}, \mathrm{~N}_{1}, \mathrm{~N}_{2}\right)$ were superimposed on the TPAN and the FLOOD treatments. Trees in TTEN plots were fertilized at the $\mathrm{N}_{1}$ rate only. Plots designated $\mathrm{NO}$ received no $\mathrm{N} ; \mathrm{N}_{1}$ received 20,40, 80, and $160 \mathrm{~g} \mathrm{~N} /$ tree per year in 1986 , 1987, 1988, and 1989, respectively, and $\mathrm{N}_{2}$ plots received twice the amounts applied to $\mathrm{N}_{1}$ plots. The $\mathrm{N}_{1}$ level approximates the rates commonly used by local growers. Liquid commercial $\mathrm{N}$ 32 fertilizer $\left(\mathrm{NH}_{4}: \mathrm{NO}_{3}=1: 1\right)$ was injected into the lines to give $200 \mathrm{mg} \mathrm{N} /$ liter in Fall 1986 and from January to JulyAugust in the remaining years. Under FLOOD, N-32 was diluted in $\approx 11$ liters of water and distributed evenly around the trees in a circle 2.5 times larger than the tree canopy. A single application was used in Aug. 1986 and split applications in January and May during the rest of the experiment. Elements other than $\mathrm{N}$ were not included in the fertilizer program because leaf $\mathrm{P}, \mathrm{K}, \mathrm{Mg}$, and $\mathrm{Ca}$ are commonly optimal or high in Texas citrus (Swietlik and LaDuke, 1985) and $\mathrm{P}$ and $\mathrm{K}$ fertilization failed to induce responses in past fertility studies (Hipp and Shun, 1976; Leyden, 1978).

Experiment design and statistical analysis. Treatments were applied to five-tree plots (experimental units) replicated four times in a split block. Nitrogen levels comprised the main plots, whereas the FLOOD, TPAN, and TTEN treatments were applied to separate rows running across the main plots as subplots. Because all TTEN rows received $\mathrm{N}$ at the $\mathrm{N}_{1}$ level, only the trees within the $\mathrm{N}_{1}$ main plots were used in the experiment. FLOOD and trickle-irrigated rows were separated by two buffer rows of which one was flood- and the other trickle-irrigated. Adjoining N plots within the rows were separated by two buffer trees. The experiment was terminated in Jan. 1990 after the freeze of Dec. 1989 destroyed the tree canopies.

In the case of FLOOD and TPAN treatments, a two way splitblock analysis of variance (ANOVA) was employed to test the significance of main effects and interactions between irrigation methods and $\mathrm{N}$ levels. Linear and quadratic regressions were used to separate $\mathrm{N}$ level means. A paired t test was used to compare the response of TTEN and TPAN trees within the $\mathrm{N}_{1}$ main plots.

Irrigation management. There was one emitter per tree (3.8 liter $\cdot h^{-1}$ ) before July 1987 and two emitters after that date. The single emitters were placed at the trunks and $60 \mathrm{~cm}$ from the trunk on opposite sides of the tree under the double emitter arrangement. Irrigation uniformity was at least $95 \%$ as periodically determined using a procedure described by Bralts (1986).

Irrigation intervals in the TPAN treatment, during rainless periods, ranged from 1 day in the summer to 14 days in the winter and were determined using a procedure described by Karmeli and Keller (1975).

Soil water potentials in the TTEN treatment were measured at 30-cm depth with a total of 24 tensiometers arranged in eight stations (two stations per replication). There were three tensiometers per station positioned 15,30 , and $45 \mathrm{~cm}$ from the emitter toward the outside of the tree along the tree row. It was determined empirically that when soil water potential reached $-0.02 \mathrm{MPa}$ at $30-\mathrm{cm}$ depth, 20 liters of water were needed to saturate the soil around the tensiometers.

A total of 12 steel access tubes $(5 \mathrm{~cm}$ in diameter, $120 \mathrm{~cm}$ long) were installed vertically in the soil at a distance of $60 \mathrm{~cm}$ from the tree trunk in FLOOD plots $(3 \mathrm{~N}$ levels $\mathrm{x} 4$ replications $=12$ tubes). Volumetric soil water content $\theta$ was determined using a neutron probe (Campbell Pacific Nuclear, Pacheco, Calif., Model 503 DR). A calibration was performed at each access tube by establishing a relationship between gravimetrically determined $\theta$ at $30-$ and $60-\mathrm{cm}$ soil depths and count ratios from the neutron probe. All calibration regressions had coefficients of determination $\left(\mathrm{R}^{2}\right)$ ranging from 0.91 to 0.95 . Available soil water was the difference between the value of $\theta$ at field capacity (determined on soil samples collected 2 days after flood irrigation) and permanent wilting point (determined by extracting soil water at $1.5 \mathrm{MPa}$ for 1 week in a pressure extractor) (Soil Moisture Equipment, Santa Barbara, Calif.).

Measurements. Tree height, canopy, and trunk diameter in north-south and east-west directions, were measured after each growing season in December-January. Fruit yield and fruit count were recorded in Feb. 1989 and Jan. 1990.

Each year, spring-cycle leaves and June-cycle leaves were collected in May-July and October-November, respectively. After washing in four changes of demineralized water, drying, and grinding, 0.5 -g samples were ashed at $500 \mathrm{C}$ overnight and dissolved in $6 \mathrm{~N} \mathrm{HCI}$ for $\mathrm{K}, \mathrm{Mg}, \mathrm{Ca}, \mathrm{Fe}, \mathrm{Zn}, \mathrm{Mn}$, and $\mathrm{Cu}$ determinations with an atomic absorption spectrophotometer. Phosphorus was determined calorimetrically in the same solution by the vanado-molybdo-phosphoric method (Jackson, 1970). Additional $0.5-\mathrm{g}$ samples were extracted with $100 \mathrm{ml}$ of $0.08 \mathrm{~N}$ $\mathrm{HNO}_{3}$. The displaced Na was determined with the atomic absorption spectrophotometer and $\mathrm{Cl}$ by titration with standard silver nitrate (Jackson, 1970). Nitrogen was determined by the Kjeldahl method using a 0.5 -g sample digested in $30 \mathrm{ml}$ concentrated $\mathrm{H}_{2} \mathrm{SO}_{4}$ with the addition of $10 \mathrm{~g} \mathrm{~K}_{2} \mathrm{SO}_{4}, 1 \mathrm{~g} \mathrm{CuSO}_{4}$, and $0.1 \mathrm{~g}$ selenium.

Root distribution. Two uniform trees from each of the FLOOD$\mathrm{N}_{1}$, TPAN-N , and TTEN-N treatments were selected for root distribution studies by use of a trench method. During March and the first half of Apr. 1990, at each tree, two 270-cm deep trenches positioned perpendicular to the tree row at 60 and 210 $\mathrm{cm}$ from the tree trunk and three trenches parallel to the tree row at 60,210 , and $430 \mathrm{~cm}$ from the trunk were dug. Roots were exposed by first soaking the profile wall with water and then washing off a $0.5-\mathrm{cm}$ layer of soil. Nails were driven into 
the profile wall to form a $15-\mathrm{cm}$ grid that served as a guide in removing the desired thickness of soil.

A wooden frame containing a transparent plexiglass plate and covered with clear plastic film was placed in front of the profile wall. Roots < 2; 2 to $5 ; 5.1$ to $10 ; 10.1$ to 20 , and $>20 \mathrm{~mm}$ thick were circled on the plastic film. Each circle represented $\approx 5$-mm root length at the profile wall. Root length density was then estimated on a soil volume basis. Root densities were calculated at $30-\mathrm{cm}$ increments down to $240-\mathrm{cm}$ soil depth.

Statistical analysis consisted of a split-split plot ANOVA with irrigation treatments constituting main plots and trench position and root depth in the soil constituting subplots and sub-subplots, respectively. Where applicable, regression analysis was used to separate depth level means, whereas irrigation method and trench position means were separated with Duncan's multiple range test.

\section{Results}

FLOOD and TPAN treatments. The annual rainfall was 630, 530,570 , and $390 \mathrm{~mm}$ in 1986 to 1989 , respectively. The precipitation was average for the area except in 1989 when it was $34 \%$ lower than a 29-year mean of $590 \mathrm{~mm}$.

During the 4 years of the study, a total of 24,410 and 1845 $\mathrm{kl}$ water/ha was applied in FLOOD and TPAN treatments, respectively. A total of 16 flood irrigations was applied with three, four, four, and five irrigations in 1986, 1987, 1988, and 1989.

The fertilization $\mathrm{x}$ irrigation method interaction was not significant for leaf concentration of any element (data not shown). Leaf $\mathrm{N}$ concentrations of TPAN trees were higher than for FLOOD trees in July 1987 ( 2.50 vs. $2.32 \%$ dry weight; $P=0.05$ ), but no differences were found on later dates (range 2.5\%-2.9910; maximum intra-annual variation $0.1 \%$ ). Leaf $\mathrm{N}$ level in July 1987, and May and Oct. 1989 increased linearly with increasing $\mathrm{N}$ rates, but no differences were noted in Oct. 1987 or July and Nov. 1988 (Table 1).

TPAN trees had lower leaf $\mathrm{P}$ and $\mathrm{K}$ and higher leaf $\mathrm{Ca}, \mathrm{Fe}$, $\mathrm{Mn}$, and $\mathrm{Cl}$ than FLOOD trees in 1987 (Table 2). No differences, except for Fe in 1988 (Table 2), occurred in 1988 and 1989 (data not shown).

As $\mathrm{N}$ rate increased there was a linear reduction $(P<0.05)$ in leaf $\mathrm{Cl}$ in 1987 and a linear increase $(P<0.05)$ in leaf $\mathrm{Mn}$ in 1989. The concentrations of $\mathrm{Cl}$ were 1100,1074 , and 1004 $\mathrm{mg} \cdot \mathrm{kg}^{-1}$ dry weight and those of $\mathrm{Mn}$ were 35,38 , and 40 $\mathrm{mg} \cdot \mathrm{kg}^{-1}$ dry weight at the $\mathrm{N}_{0}, \mathrm{~N}_{1}$, and $\mathrm{N}_{2}$ rates, respectively. No other elements were affected by $\mathrm{N}$ nutrition.

Trunk diameter, canopy width, and tree height were not af-

Table 1. Influence of irrigation method and $\mathrm{N}$ rate on leaf $\mathrm{N}$ concentration in young 'Ray Ruby' grapefruit trees on sour orange rootstock.

\begin{tabular}{lcccccc}
\hline \hline & \multicolumn{7}{c}{ Leaf N (\% dry wt) } \\
\cline { 2 - 7 } N rate & July & Oct. & July & Nov. & May & Oct. \\
& 1987 & 1987 & 1988 & 1988 & 1989 & 1989 \\
\hline $\mathrm{N}_{0}{ }^{2}$ & 2.32 & 2.77 & 2.64 & 2.74 & 2.79 & 2.43 \\
$\mathrm{~N}_{1}$ & 2.42 & 2.76 & 2.67 & 2.79 & 2.86 & 2.55 \\
$\mathrm{~N}_{2}$ & 2.50 & 2.77 & 2.69 & 2.80 & 2.94 & 2.56 \\
Linear & $* *$ & NS & NS & NS & $*$ & $* *$ \\
Quadratic & NS & NS & NS & NS & NS & NS \\
\hline
\end{tabular}

${ }^{z} \mathrm{~N}_{0}=$ no $\mathrm{N} ; \mathrm{N}_{1}=20,40,80$, and $160 \mathrm{~g} \mathrm{~N} /$ tree per year in 1986 , 1987, 1988, and 1989, respectively; $\mathrm{N}_{2}=$ twice the amount of $\mathrm{N}_{1}$. , $*$, **Nonsignificant or significant at $P^{2}=0.05$ or 0.01 , respectively, by $\mathrm{F}$ test.
Table 2. Influence of irrigation method and $\mathrm{N}$ rate on leaf mineral composition in young 'Ray Ruby' grapefruit trees on sour orange rootstock.

\begin{tabular}{|c|c|c|c|c|c|c|c|}
\hline \multirow{3}{*}{$\begin{array}{l}\text { Irrigation } \\
\text { method }\end{array}$} & \multicolumn{7}{|c|}{ Leaf mineral concn } \\
\hline & \multicolumn{6}{|c|}{ Oct. 1987} & \multirow{2}{*}{$\begin{array}{l}\text { Nov. } \\
1988 \\
\mathrm{Fe}\end{array}$} \\
\hline & $\mathrm{P}$ & $\mathrm{K}$ & $\mathrm{Ca}$ & $\mathrm{Cl}$ & $\mathrm{Fe}$ & $\mathrm{Mn}$ & \\
\hline & \multicolumn{3}{|c|}{$\%$ dry $w t$} & \multicolumn{4}{|c|}{$m g \cdot k g^{-1} d r y w t$} \\
\hline FLOOD & 0.18 & 1.45 & 3.29 & 982 & 82 & 45 & 78 \\
\hline TPAN $^{z}$ & 0.16 & 1.31 & 3.89 & 1137 & 89 & 57 & 81 \\
\hline Significance & $* *$ & $* *$ & $*$ & $*$ & * & $*$ & $*$ \\
\hline
\end{tabular}

${ }^{2}$ TPAN $=$ trickle irrigations scheduled based on Class A pan evaporation.

$*$,** Significant at $P=0.05$ or 0.01 according to $\mathrm{F}$ test.

Table 3. Influence of $\mathrm{N}$ fertilization on yield of young 'Ray Ruby' grapefruit trees on sour orange rootstock, 1989.

\begin{tabular}{lccc}
\hline \hline Treatment & $\begin{array}{c}\text { Yield/tree } \\
(\mathrm{kg})\end{array}$ & No. fruit/tree & $\begin{array}{c}\text { Fruit wt } \\
(\mathrm{g})\end{array}$ \\
\hline $\mathrm{N}_{0}^{\mathrm{z}}$ & 12.4 & 33 & 394 \\
$\mathrm{~N}_{1}$ & 16.4 & 41 & 400 \\
$\mathrm{~N}_{2}$ & 19.3 & 53 & 371 \\
Linear & $*$ & $*$ & $* *$ \\
Quadratic & $\mathrm{NS}$ & $\mathrm{NS}$ & $*$ \\
\hline
\end{tabular}

${ }^{2} \mathrm{~N}_{0}=$ no nitrogen $\mathrm{N}_{1}=20,40,80$, and $160 \mathrm{~g} \mathrm{~N} /$ tree per year in 1986, 87, 88, and 89, respectively; $\mathrm{N}_{2}=$ twice the amount of $\mathrm{N}_{1}$.

, ,*,** Nonsignificant or significant at $P=0.0 .5$ or 0.01 , respectively, by $\mathrm{F}$ test.

fected by the treatments on any date of measurement, except in Jan. 1989, when a linear increase $(P<0.05)$ in trunk diameter of 67,69 , and $72 \mathrm{~mm}$ for the $\mathrm{N}_{0}, \mathrm{~N}_{1}$, and $\mathrm{N}_{2}$ treatments was noted.

The trees produced the first crop in 1988, which ranged from 1.8 to $4.7 \mathrm{~kg} /$ tree with no significant differences between treatments (data not shown). In 1989; there was a linear increase in yield and fruit count in response to increasing $\mathrm{N}$ levels (Table 3). Mean fruit weight was smaller at $\mathrm{N}_{2}$ than at $\mathrm{N}_{0}$ and $\mathrm{N}_{1}$ levels, probably because of the higher fruit count per tree.

TPAN and TTEN treatments. In 1986, about equal amounts of water were applied to TPAN and TTEN trees, but afterward more water was applied under the TPAN regime (Fig. la). A total of 1845 and $853 \mathrm{kl}$ water/ha was applied in TPAN and ITEN treatments, respectively. Using TTEN irrigation rates, water needs under trickle irrigation could be expressed as 0.75 , $0.57,0.30$, and 0.20 of Class A pan evaporation in 1986, 1987, 1988, and 1989 (Fig. lb).

In 1989, TTEN trees had larger trunk diameters $(P<0.05)$ and were taller $(P<0.01)$ than TPAN trees (trunk diameter 98 vs. $93 \mathrm{~mm}$; tree height 229 vs. $214 \mathrm{~cm}$ ). No other differences in vegetative growth were noted, and there were no differences in fruit yield, fruit count or average fruit weight in any year of the study (data not shown).

Root distribution and density. RLD decreased with depth in all irrigation treatments, but FLOOD trees had higher RLD than TPAN and TTEN trees in the top $30 \mathrm{~cm}$ of soil and lower RLD at 90 - to $210-\mathrm{cm}$ depth (Fig 2). Irrigation $\mathrm{x}$ depth linear, quadratic, and cubic interactions were significant $(P<0.01)$ for changes in RLD with depth. TPAN and TTEN trees had $57 \%$ and FLOOD trees only $17 \%$ of their roots at depth $>60 \mathrm{~cm}$. The maximum vertical root extension was $230 \mathrm{~cm}$ for all irrigation methods. 
KILOLITERS PER HECTARE

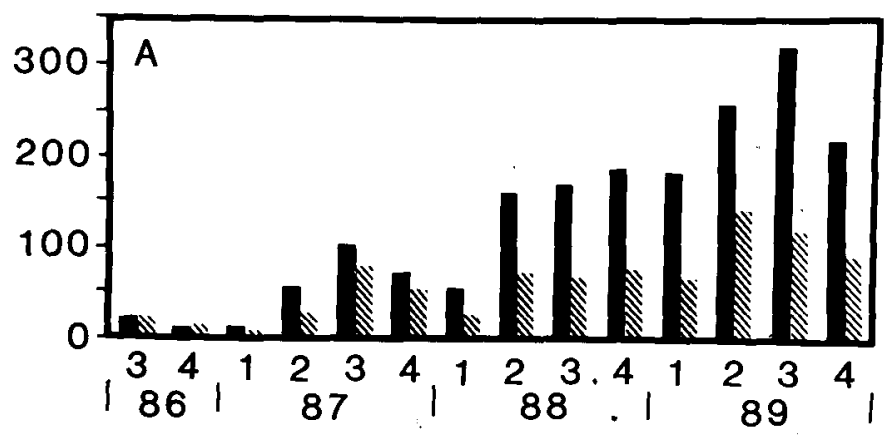

YEAR'S QUARTER

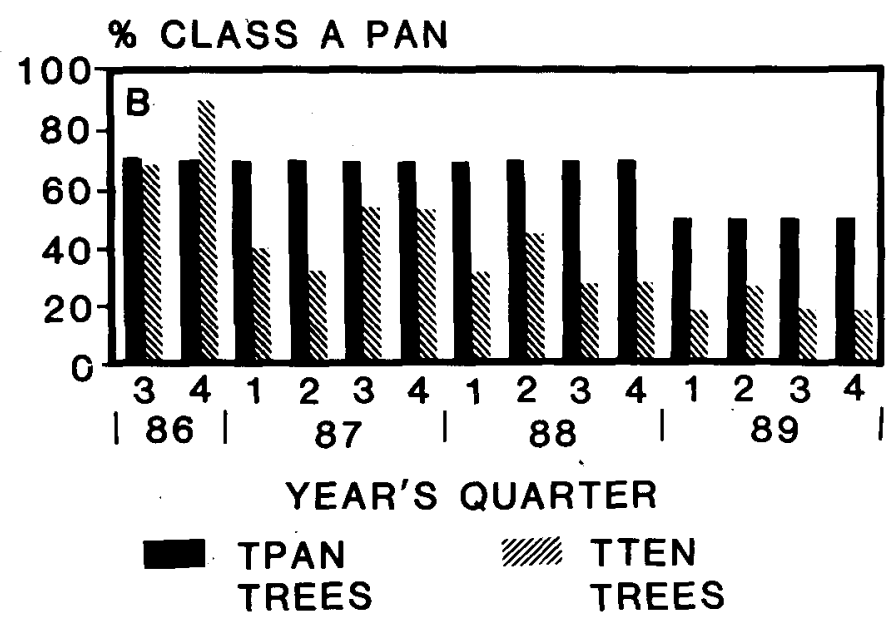

Fig. 1. Quarterly irrigation amounts in trickle-irrigated young 'Ray Ruby' grapefruit trees expressed as (A) kiloliters per hectare, or (B) a fraction of Class A pan evaporation adjusted to the ground area covered by the tree canopies.

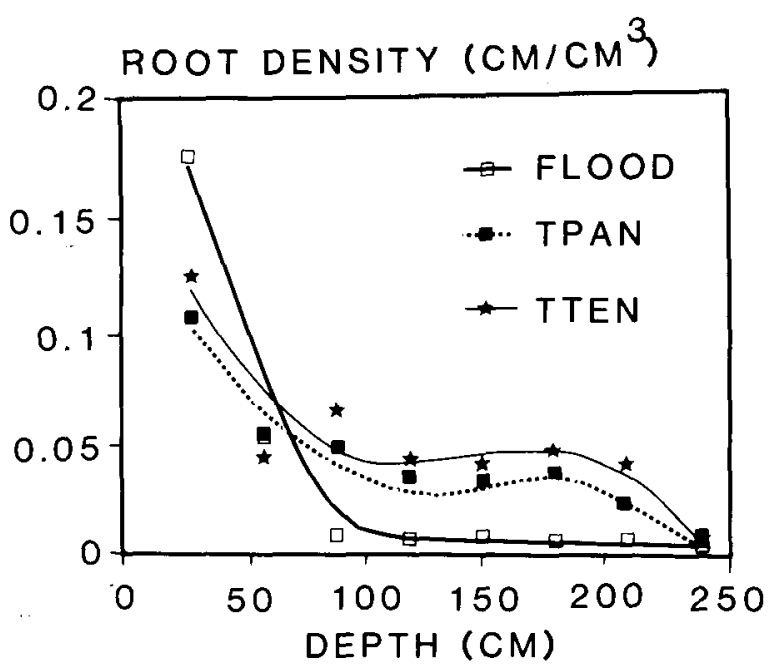

Fig.2. Influence of irrigation method enroot density changes with soil depth in young 'Ray Ruby' grapefruit trees on sour orange rootstock. Data presented are averaged over different trench positions. Each data point represents 10 measurements. Irrigation $\mathrm{x}$ depth linear, quadratic, and cubic interactions were significant at $\boldsymbol{P}$ $<0.01$.
In all irrigation treatments, RLD decreased with increasing distance from the trunk. At 60,210, and $430 \mathrm{~cm}$ from the trunk, between rows, RLD was $0.055,0.031$, and $0.002 \mathrm{~cm} \cdot \mathrm{cm}^{-3}$, respectively; each value was significantly different from the others $(\mathrm{P}<0.01)$. Only roots of FLOOD trees extended as far as $430 \mathrm{~cm}$ from the trunk.

Only a few dead roots were observed in this study conducted 2 to 3.5 months after the trees were freeze-damaged. The trees recovered from freeze injuries, but extensive death of roots was observed in a follow-up study conducted in the same orchard 7 months after the freeze (data not shown).

\section{Discussion}

In this study, I compared the growers' practice of applying flood irrigations to the whole orchard floor with trickle irrigations applied to limited soil surfaces. Thus, water savings in excess of $90 \%$ realized under trickle irrigation reflect realistically attainable savings in commercial orchards. The present savings were larger than the $82 \%$ saving reported in an earlier study (Leyden, 1975a). In that study, however, flood irrigations were applied to strips of soil rather than the entire orchard floor. Few growers use strip irrigation, because savings on water do not compensate for increased cost of building and maintaining additional soil borders.

Tree vegetative growth was similar under trickle and flood irrigation, which supports the earlier finding that trickle irrigation does not improve tree establishment on fine-textured soils in Texas (Leyden, 1975a). Based on my study, a similar conclusion can now be drawn in respect to earliness of fruiting. The data differ from the 1977 findings of Proebsting et al. for apple (Malus domestica Borkh.) where trickle irrigation promoted precocious bearing. The fact that they used a different tree species and conducted their study in an area of lower rainfall compared to our site could explain the difference in response. No published reports could be found on effects of irrigation method on early production of citrus.

The trees did not respond to $\mathrm{N}$ fertilization until the fourth growing season, when the $\mathrm{N}_{2}$ treatment of $320 \mathrm{~g} \mathrm{~N} /$ tree per year produced the highest fruit yield. Even then, however, the control trees had optimal leaf $\mathrm{N}$ levels according to current standards (Embleton et al., 1973). Under different soil and climatic conditions, different responses have been obtained (Willis et al., 1991). Thus, caution should be exercised not to extrapolate the current results beyond the conditions of this experiment.

When the trees responded to $\mathrm{N}$ in the fourth growing season, frequent $\mathrm{N}$ fertigations from January to August provided no benefits compared to two split broadcast applications as practiced under flood irrigation. Similar results were reported for mature citrus trees in Florida (Koo, 1984) and Israel (Dasberg et al., 1988) and for young trees in Florida (Willis et al., 1991).

Mineralization of organic N, lack of weed competition, tree $\mathrm{N}$ reserves carried from the nursery, and the generally small $\mathrm{N}$ requirements of young trees may help to explain the prolonged lack of tree responses to $\mathrm{N}$ fertilization. Nitrogen may have also been derived from residual soil inorganic $\mathrm{N}$ from past $\mathrm{N}$ fertilizations. More research is needed to clarify the role of these and possibly other factors if the goal of improving $\mathrm{N}$ efficiency and minimizing the environmental impact of $\mathrm{N}$ fertilizers is to be attained.

The assumption that soil water was not a limiting factor in the TTEN treatment was apparently correct, because the higher irrigation amounts applied to the TPAN trees did not improve their growth and fruiting. The water needs in the 2 nd to the 4 th 
years, derived from the TTEN irrigation amounts and expressed as a fraction of Class A pan evaporation adjusted to a tree canopy size, are lower than the 0.7 Class A pan evaporation used by Leyden (1975b) for mature citrus trees. The decreasing trend in the values of pan coefficients as trees aged indicates that continuous root expansion outside the irrigated zones enhanced the use of soil water reserves derived from rainfall. The fact that the trickle irrigations modified the trees' nutritional status in the initial but not later stages of the experiment also suggests that an active root system existed outside the irrigated zones as trees aged.

Trickle-irrigated trees had better access to water stored in the deep soil layers and capillary water from the water table because, compared to FLOOD trees, their RLD was higher at greater soil depths (90 to $210 \mathrm{~cm}$ ). Thus, the substantial water savings with trickle irrigation may be attributed to not only the improved irrigation' efficiency but also changes in vertical root distribution. In Arizona, Roth and Gardner (1985) observed higher root concentrations in deeper soil layers of trickle- than floodirrigated 'Valencia' orange trees, but soil depths $>150 \mathrm{~cm}$ were not explored. Nevertheless, their and my results show that trickle irrigation had similar effects on vertical root distribution in arid Arizona and more humid southern Texas.

Rooting at greater soil depths was promoted by favorable water conditions coupled with periodic suboptimal moisture conditions in the upper soil layers outside the irrigated zones. Similarly, Cahoon et al. (1961) found more deep roots under 'Washington Navel' orange trees subjected to few than to frequent furrow irrigation. The importance of optimal soil water content for root growth in citrus and other fruit trees was reported in other studies (Beuke, 1984; Bevington and Castle, 1985; Castle, 1978; Layne et al., 1986). Root penetration to $230 \mathrm{~cm}$ was unexpected, considering the clay texture of the top 90- to 130-cm soil layer. Although Castle and Krezdorn (1975) and Ford (1954) reported maximal vertical extension of sour orange roots to be 350 to $510 \mathrm{~cm}$ on deep sandy soils, the extent of root growth below $120 \mathrm{~cm}$ depth was not reported in studies conducted on more finely textured soils (Bielorai, 1985; Morshet et al., 1989; Roth and Gardner, 1985). Adriance and Hampton (1949) showed that roots of 'Marsh' grapefruit on sour orange rootstock grew below $152 \mathrm{~cm}$ in a deep, well-drained, clayloam soil in Texas, but the maximal downward root extension was not specified.

Roots did not concentrate in irrigated zones, which suggests either the existence of adverse conditions for root growth in wetted zones, e.g., poor soil aeration (Atkinson, 1980), or sufficient water for root growth in the nonirrigated zone. In arid climates, higher root densities are common in irrigated compared to nonirrigated soil zones (Bielorai, 1985; Levin et al., 1980; Morshet et al., 1989; Roth and Gardner, 1985). In some of these studies (Bielorai, 1985; Morshet et al., 1989), the irrigated zones were nearer the trunk than the nonirrigated ones. The present results show, however, that the distance from the trunk is an important consideration in data interpretation. In two other studies conducted in humid climates, similar root densities in the, irrigated and nonirrigated zones were observed (Huguet and Furcade, 1980; Koo and Smajstrla, 1985).

The major benefit of trickle vs. flood irrigation found in this study was the substantial saving of irrigation water without negatively affecting tree growth and early fruiting performance. Under the climatic conditions of southern Texas, roots of trickle-irrigated trees will grow outside the wetted zones and may extend to at least $230 \mathrm{~cm}$ soil depth. Since the magnitude of water contribution from outside the wetted zones is difficult to assess, there is a need for characterization of plant variables for irrigation scheduling.

\section{Literature Cited}

Adriance G.W. and H.E. Hampton. 1949. Root distribution in citrus as influenced by environment. Proc. Amer. Soc. Hort. Sci. 53:103108.

Atkinson, D. 1980. The distribution and effectiveness of the roots of tree crops. Hort. Rev. 2:424-490.

Beuke, D.J. 1984. Apple root distribution as affected by irrigation at different soil water levels and two soil types. J. Amer. Soc. Hort. Sci. 109:723-728.

Bevington, K.B. and W.S. Castle. 1985. Annual root growth pattern of young citrus trees in relation to shoot growth, soil temperature, and soil water content. J. Amer. Soc. Hort. Sci. 110:840-845.

Bielorai, H. 1982. The effect of partial wetting of the root zone on yield and water use efficiency in a drip- and sprinkler-irrigated mature grapefruit grove. Irr. Sci. 3:89-100.

Bielorai, H. 1985. Moisture, salinity and root distribution of drip irrigated grapefruit. Proc. Third Intl. Drip/Trickle Irr. Congr. 2:579_ 586.

Bielorai, H., S. Dasberg, and Y. Emer. 1985 Long-term effects of partial wetting in a citrus orchard. Proc. Third Intl. Drip/Trickle Irr. Congr. 2:568-573.

Black, J. D. F., P.D. Mitchell, and P.N. Newgreen. 1977. Optimum irrigation rates for young trickle-irrigated peach trees. Austral. J. Expt. Agr. Animal Husbandry 17:342-345.

Bralts, V.F. 1986. Emitter discharge uniformity estimations, p. 218227. In: F.S. Nakayama and D.A. Bucks (eds.). Trickle irrigations for crop production. Design, operation, and management. Elsvier, Amsterdam.

Cahoon, G. A., M.R. Huberty, and M.J. Garber. 1961. Irrigation frequency effects on citrus root distribution and density. Proc. Amer. Soc. Hort. Sci. 77:167-172.

Castle, W.S. 1978. Citrus root systems: their structure, function, growth, and relationship to tree performance. 1978 Proc. Intl. Soc. Citricult. 1:62-69.

Castle, W.S. and A.H. Krezdom. 1975. Effect of citrus rootstock on root distribution and leaf mineral content of 'Orlando' tangelo trees. J. Amer. Soc. Hort. Sci. 100:1-4.

Dasberg, S., A. Bar-Akiva, S. Spazisky, and A. Cohen. 1988. Fertigation versus broadcasting in an orange grove. Fert. Res. 15:147154.

Embleton, T. W., W.W. Jones, C.K. Labanauskas, and W. Reuther. 1973. Leaf analysis as a diagnostic tool and guide to fertilization, p. 183-210. In: W. Reuther (cd.). The citrus industry, vol. 3. Univ. of Calif., Berkeley.

Ford, H.W. 1954. The influence of rootstock and tree age on root distribution in citrus. Proc. Amer. Soc. Hort. Sci. 63:137-142.

Hipp, B.W. and A.V. Shun. 1976. Influence of nitrogen, phosphorus, and potassium on red grapefruit. J. Rio Grande Valley Hort. Soc. 30:65-72.

Huguet, J.G. and P. Furcade. 1980. Apple tree root distribution in relation to the position of drip irrigation nozzles, p. 59-67. In: K. Slowik, D. Swietlik, and K. Sitton (eds.). Proc. Symp. Drip. Irr. Hort., Skierniewice, Poland, 30 Sept.-4 Oct. 1980.

Jackson, M.L. 1970. Phosphorus determinations for soils. Vanadomolybdo-phosphoric yellow color method in nitric acid system, p. 151-154. In: M.L. Jackson (cd.). Soil chemical analysis. PrenticeHall, Englewood Cliffs, N.J.

Karmeli, D. and J. Keller. 1975. Trickle irrigation design. Rain Bird Sprinkler Manufacturing Corp. Glendora, Calf.

Koo, R.C.J. 1984. The importance of ground coverage by fertigation for citrus on sandy soils. Fert. Issues 1:75-78.

Koo, R.C.J. 1985. Response of 'Marsh' grapefruit trees to drip, undertree spray and sprinkler irrigation. Proc. Fla. State Hort. Soc. 98:2932. 
Koo, R.C.J. 1989. Use of controlled-release nitrogen for citrus in humid regions. 1988 Proc. Intl. Soc. Citricult. 2:633-642.

Koo, R.C.J. and A.G. Smajstrla. 1985. Trickle irrigation of citrus on sandy soils in a humid region. Proc. Third Intl. Drip/Trickle Irr. Congr. 1:212-219.

Layne, R. E. C., C.S. Tan, and R.L. Perry. 1986 Characterization of peach roots in fox sand as influenced by sprinkler irrigation and tree density. J. Amer. Soc. Hort. Sci. 111:670-677.

Levin, I., R. Assaf, and B. Bravdo. 1980. Irrigation, water status and nutrient uptake in an apple orchard, p. 255-264. In: D. Atkinson, J.E. Jackson, R.O. Sharples, and W.M. Wailer (eds.). Mineral nutrition of fruit trees. Butterworths, London.

Leyden; R.F. 1975a. Comparison of three irrigation systems for young citrus trees. J. Rio Grande Valley Hort. Soc. 29:25-30.

Leyden, R.F. 1975b. Drip irrigation on bearing citrus trees. J. Rio Grande Valley Hort. Soc. 29:31-36.

Lcyden, R.F. 1978. Nitrogen and phosphorus fertilization of red grapefruit. J. Rio Grande Valley Hort. Soc. 32:55-59.

Marler, T.E. and F.S. Davies. 1990. Microsprinkler irrigation and growth of young 'Hamlin' orange trees. J. Amer. Soc. Hort. Sci. 115:45-51.

Morshet, S., Y. Cohen, and M. Fuchs. 1989. Water use and yield of a mature 'Shamouti' orange orchard submitted to root volume re- striction and intensive canopy pruning. 1988 Proc. Intl. Soc. Citricult. 2:739-746.

Proebsting, E. L., J.E. Middleton, and S. Roberts. 1977. Altered fruiting and growth characteristics of 'Delicious' armies associated with irrigation method. HortScience 12:349-350.

Roth, R.L. and B.R. Gardner. 1985. Root distribution of mature orange trees irrigated by pressurized systems. Proc. Third Intl. Drip/ Trickle Irr. Congr. 2:579-586.

Roth, R. L., D.R. Rodney, and B.R. Gardner. 1974. Comparison of irrigation methods, rootstock, and fertilizer elements on 'Valencia' orange trees. Proc. 2nd Intl. Drip Irr. Congr. 103-108.

Smajstrla, A.G. and R.C.J. Koo. 1984. Effects of trickle irrigation methods and amounts of water applied on citrus yields. Proc. Fla. State Hort. Soc. 97:3-7.

Smajstrla, A. G., L.R. Parsons, K. Aribi, and G. Veliedis. 1985. Response of young citrus trees to irrigation. Proc. Fla. State Hort. Soc. 98:25-28.

Swietlik, D. and J.V. LaDuke. 1985. Nutritional status and growth responses of freeze-injured citrus trees to mineral foliar sprays in the first year of recovery. J. Rio Grande Valley Hort. Soc. 38:51-58.

Willis, L. E., F.S. Davies, and D.A. Graetz. 1991. Fertigation and growth of young 'Hamlin' orange trees in Florida. HortScience 26:106 109. 